\title{
THE EFFICIENCY OF CONTROL TESTS FOR THE EVALUATION OF MULTILATERAL PHYSICAL TRAINING IN ADVANCED LEVEL 14-15 YEAR OLD FEMALE ATHLETES
}

\author{
Scurt C. \\ cornelscurt@yahoo.com \\ Transilvania Universityof Brașov
}

\begin{abstract}
:
The research hypothesis starts from the premise that the efficiency of using the evidence of verifying the multilateral physical training is a useful method for advanced level female athletes.

The aim of the research is to improve the means of training and the structure of the competitive calendar by restructuring the training to obtain the optimal sports form in the competition of objectives.

The topic of the research is represented by the methods and means of training as well as the structure of the competitive calendar.

The practical value of the research consists in the possibility to elaborate training models that are useful to the specialists in the field.
\end{abstract}

Keywords: training, competition, control tests.

Introduction:

The training and competition efforts are valid for both perspective and performance athletes.

The body of the adult is in the period of growth and development compared to that of children and juniors and a period of development of the capacity for effort specific to age without being completely exhausted and without making the mistake which is practiced by some coaches who apply the content of the training almost identically.

The competition is one of the most important means of training, representing and systematically verifying the potential of athletes. An essential thing is the experience of the competition, the recommendation being that the participation should be made at an optimal number of starts. Each athlete will improve their own competition experience, by increasing the capacity for specific effort.

The formation of a great value, multilateral and harmonious personality, the achievement of high performances is the purpose of training and as tasks we nominate (Gârlranu.-D.-2009):

-formation of motor skills,

-development of motor skills,

- mastering the test technique,

-the acquisition of theoretical knowledge,

-development of qualities and skills specific to the test,

-education of the moral-volitional qualities of the athlete

Achieving high value performance is the prerogative of athletes with real qualities who throughout the years have achieved high energy waste and the athlete feels able to achieve high performance.

The programming of the competitions will be carried out according to the objective of the competition for which the athlete prepares. The objective of the competitions can be: the national championship finals for national level athletes and competitions for world level athletes (O.G, W.C.).

In order to achieve the participation for the objective of the competition, the athlete is in the optimal state of sports form, reflected by above the average results achieved at the control tests at the end of the preparatory period (Alexe, N., 1993) 
The control tests can be applied depending on the nature of the effort, and at the beginning of the preparatory period.

Matherial and method:

In order to develop the reaction and execution speed, there will have to be a concern for mastering the technique and improving the neuromuscular coordination (Demeter., A, -1981).

For the development of strength in speed regime, and for the education of the focusing ability of the attention and ability to perform speed efforts (Baciu, C. 1977).

The education of muscle relaxation. The exercises for the development of speed capacity are performed on a rested body, usually after the fundamental part of the lesson, the use of increased volumes and intensities without an adequate basis of multilateral physical training leads to premature installation of the speed barrier (Demeter., A 1981).

For the analytical development of the strength of the main muscle groups, the development of the explosive force against the background of jumps and throws in speed regime (Demeter., A., 1981, Baciu., C.1977)

The development of the aerobic resistance is achieved by uninterrupted effort, while the local neural-muscular resistance by analytical exercises for the development of the major muscle groups (Demeter., A., 1980)

The anaerobic lactic resistance will be developed through repeated runs, 25-40/ sec with 2-3 repetitions in 2-3 sets/ training.

Considering the previous accumulations, the development of the motor qualities is continued, increasing the dosage of the means used. (Gîrleanu., D, -Tanasescu., I-1981)

As training tasks we will aim at: developing the reaction speed and the execution of singular and repeated motor acts, developing the explosive and maximum force, developing the explosive force, developing the resistance in aerobic and mixed regime.

The finalities regarding the multilateral physical training, the level of motor qualities, of the specific motor skills and of the performance capacity, will be periodically verified by means of control tests (RAF, Athletics Program. 1987).

The results of the control tests compared to the requirements for each athlete entitle the one who has completed the internship at the value level of beginners will be promoted to a higher value level (ERM., Practical sports training, ATHLETICS, 2009).

The training program was designed in such a way that it assesses the level of multilateral physical training at the value level of the athletes (Table 2)

The level at which it will be measured is in Table 2, and it presents a comparative analysis of the results obtained by a group of girls aged 14-15, legitimized at CSM Brașov with the objective of being promoted to the performance group in 2017. 


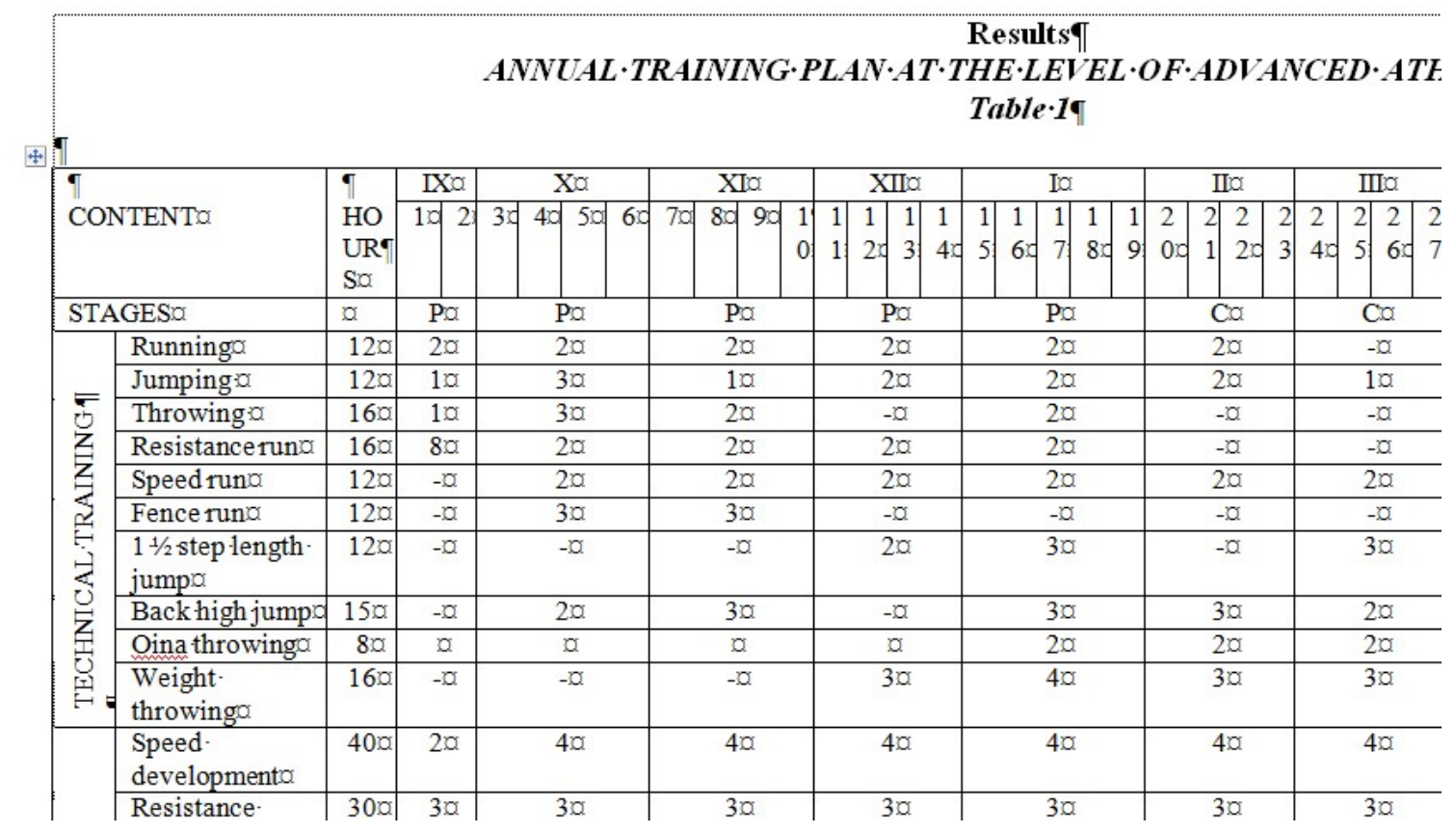

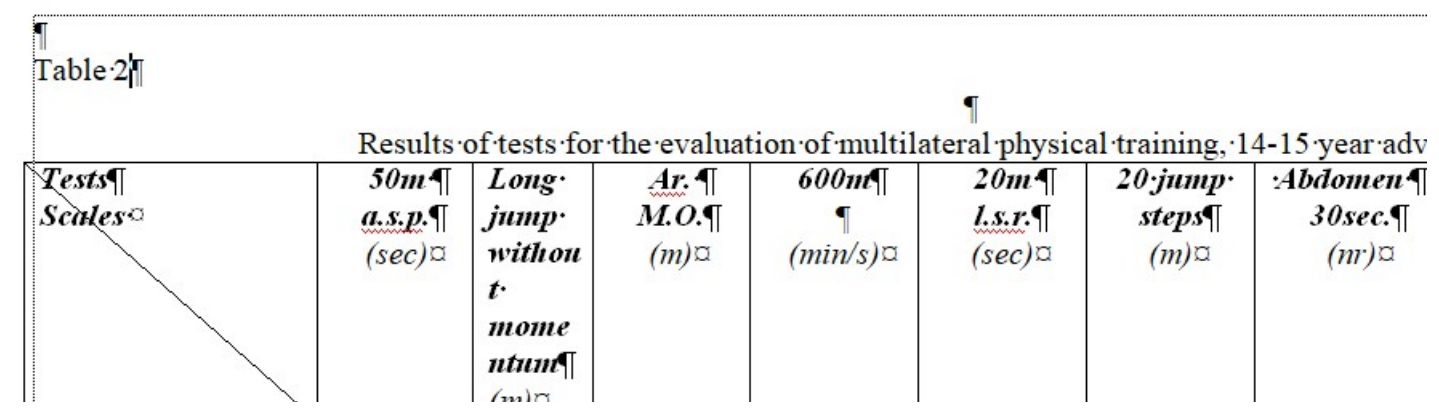

Height and age criteria Table 3

\begin{tabular}{|c|c|c|c|}
\hline \multicolumn{2}{|c|}{ Age } & 14 years & 15 years \\
\hline \multirow{6}{*}{ GIRLS } & T.E & 1.65 & 1.68 \\
\cline { 2 - 4 } & DP. & 1.70 & 1.73 \\
\cline { 2 - 4 } & D.D. & 1.68 & 1.75 \\
\cline { 2 - 4 } & A.A. & 1.66 & 1.69 \\
\hline
\end{tabular}

The annual training plan was designed in two macrocycles, the first macrocycle aiming to accomplish the tasks related to the development of some motor acts to ensure the formation of the training base to achieve participation in the competition.

According to the annual training plan, it results that in the first macrocycle, the share of training means is of particular importance because it ensures the correct acquisition of the technique of tests for the verification of multilateral physical training. 
The number of trainings performed weekly are 4 and the length of a training lesson is 2 hours, the topic is the acquisition of basic motor skills and the acquisition of multilateral physical training.

Speed running, resistance running, fencing, jumping represents part of the training in indoor space.

Among the throwing events oina throwing and weight throwing are scheduled as tests in the polyathlon.

Among the multilateral physical training tests, they are scheduled weekly with an hour / lesson share. The training and participation in competitions are of particular importance especially in the second macrocycle with the aim of achieving sportsmanship in the competition.

From the analysis of the results it results that the sportswomen contributed to the accomplishment of the training tasks and the control tests were worked through accordingly.

Below we present a model regarding the structure of the weekly training cycle during the winter preparatory period:

-A1-warming running $2 \mathrm{~km}$,

-mobility and flexibility exercises: $10-15 \mathrm{~min}$,

-special running and jumping exercises, $6 \times 30 \mathrm{~m}$

-launched running $4 \times 60 \mathrm{~m}$,

-accelerated running $2 \times 30 \mathrm{~m}$

-repeated running $6 \times 50 \mathrm{~m}, 92-95 \%$,

-repeated running $3 \times 30 \mathrm{~m}, 95-97 \%$,

-closing run 4-600m,

A2- warming running $2 \mathrm{~km}$,

-mobility and flexibility exercises $10-15 \mathrm{~min}$,

-special running and jumping exercises, $6 \times 30 \mathrm{~m}$

- launched running 4x40m,

-A3special exercises series of 6 elements $\times 30 m$,

- launched running $4 \times 50 \mathrm{~m}$,

-accelerated running $6 \times 40 \mathrm{~m}$,

-closing run $4-600 \mathrm{~m}$,

- PFG exercises, 25-30min.

A3 - warming running $2 \mathrm{~km}$,

-mobility and flexibility exercises $10-15 \mathrm{~min}$,

-special running and jumping exercises, $6 \times 30 \mathrm{~m}$

- launched running $4 \times 40 \mathrm{~m}$,

- accelerated running $2 \times 30 \mathrm{~m}$

-repeated running $4 \times 80 \mathrm{~m}, 95-97 \%$,

-repeated running $3 \times 30 \mathrm{~m}, 95-97 \%$,

-closing run $4-600 \mathrm{~m}$,

A4 - warming running $2 \mathrm{~km}$,

-mobility and flexibility exercises $10-15 \mathrm{~min}$,

-special running and jumping exercises, $6 \times 30 \mathrm{~m}$

- launched running $4 \times 40 \mathrm{~m}$,

- accelerated running $2 \times 25 \mathrm{~m}$

-repeated running $4 \times 80 \mathrm{~m}, 92-95 \%$,

-repeated running $3 \times 30 \mathrm{~m}, 95-97 \%$,

-closing run $4-600 \mathrm{~m}$, 
Training model regarding the structure of the weekly training cycle during the summer competition period:

-A1- warming running $1,5 \mathrm{~km}$,

-mobility and flexibility exercises $10-15 \mathrm{~min}$,

-special running and jumping exercises, $6 \times 30 \mathrm{~m}$

- launched running 4x40m,

- accelerated running $2 \times 25 \mathrm{~m}$

-repeated running $6 \times 60 \mathrm{~m}, 95-97 \%$,

-repeated running $3 \times 30 \mathrm{~m}, 95-97 \%$,

-closing run 4-600m,

A2- warming running $2 \mathrm{~km}$,

-mobility and flexibility exercises $10-15 \mathrm{~min}$,

-special running and jumping exercises, $6 \times 30 \mathrm{~m}$

- launched running $4 \times 40 \mathrm{~m}$,

-A3special exercises series of 6 elements $x 30 \mathrm{~m}$,

- launched running $4 \times 50 \mathrm{~m}$,

- accelerated running $6 \times 40 \mathrm{~m}$,

-closing run $4-600 \mathrm{~m}$,

- PFG exercises, 25-30min.

A4 - warming running $2 \mathrm{~km}$,

-mobility and flexibility exercises $15-20 \mathrm{~min}$,

-special running and jumping exercises, $6 \times 30 \mathrm{~m}$

- launched running $4 \times 40 \mathrm{~m}$,

- accelerated running $2 \times 30 \mathrm{~m}$

-repeated running 4x80m, 95-97\%,

-repeated running $3 \times 30 \mathrm{~m}, 95-97 \%$,

-closing run $4-600 \mathrm{~m}$.

\section{Research results (Table 2):}

- at the $50 \mathrm{~m}$ launched start running test for testing the speed, the scale for evaluation is met by three athletes

- at the spot long jump test, the imposed scale is $2.25 \mathrm{~m}$ the performance is not achieved by any athlete

- throw of the oina ball is also an evaluation test in which 3 out of 4 sportswomen manage to achieve the promotion scale

- in the test where cardio-respiratory resistance is tested there are low scales due to the fact that the material basis does not correspond to the purpose for which it is intended

-at the launched start running test, the scale is $2.4 \mathrm{sec}$, level exceeded by only one athlete

- torso flexion with upper limb stretching for flexibility assessment.

- in the test on the traction at the fixed bar the imposed scale is very severe 6 tractions, no athlete succeeds to achieve the scale.

\section{CONCLUSIONS}

The evaluation of the multilateral physical training is carried out by means of control tests, which in collaboration with the provided requirements will give the right to continue or not at a higher value level.

The development of motor qualities at this level is also done against the background of previous accumulations. 
The finalities regarding the multilateral physical training, the level of the specific motor qualities, the specific motor skills will be checked periodically through the control tests, compared to the stipulated requirements, will give athletes the right to continue the performance sport.

\section{RECOMMENDATIONS}

Periodic evaluation of multilateral physical training at scheduled dates.

Avoid approaching high intensities without a basis meant to avoid the premature installation of the speed barrier.

The method of uninterrupted effort will be used in order to develop aerobic resistance.

\section{References}

1. Alexe., N.,-Antrenamentul sportiv modern, Ed. Aditis, Bucuresti, 1993.

2. Baciu,C.,Anatomia funcțională, și biomecanica, aparatului locomotor, Ed.Sport-Turism, 1977.

3. Balint.,-L.,-Teoria educatiei fizice și sportului, Ed.Universității Transilvania, 2003.

4. Baciu,C , Anatomoia funcțională, și biomecanica, aparatului locomotor, Ed.Sport-Turism, 1977.

5. Gârlranu.-D.-Ghidul viitorului atlet de performanță, Ed, Printech, București, 2009.

6. Gîrleanu., D,-Tanasescu.,I-Poliatloane, pregătirea copiilor și juniorilor, 1981

7. Drăgan, I., Gurău., Selecția și orientarea medico-sportivă, în sport.Ed,Sport-Turism, 1989.

8. Demeter., A., -Bazele fiziologice și biochimice ale calităților motrice, București, ed, Sport Turism, 1981.

9. Rață., D.,-Ababei.,C.,-Predarea atletismului în școală. Ed. ALMA MATER, Bacău, 2002.

10. CNEFS.,-criterii probe și norme pentru selectia în atletism, 1987.

11. MEC, 2009-Pregătirea sportivă practică. 2009.

12. MEC-Criterii de talie și vârstă. 2009.

13. FRA-Programa din ATLETISM 